\title{
Is dry soil planting an adaptation strategy for maize cultivation in semi-arid Tanzania?
}

\author{
Marcos A. Lana ${ }^{1,2} \cdot$ Ana Carolina F. Vasconcelos ${ }^{3} \cdot$ Christoph Gornott $^{4} \cdot$ \\ Angela Schaffert ${ }^{5}$. Michelle Bonatti ${ }^{2}$. Johanna Volk ${ }^{6}$. Frieder Graef ${ }^{2}$. \\ Kurt Christian Kersebaum ${ }^{2} \cdot$ Stefan Sieber ${ }^{2}$
}

Received: 10 July 2017 / Accepted: 10 November 2017 / Published online: 29 December 2017

(C) The Author(s) 2017. This article is an open access publication

\begin{abstract}
Agriculture has the greatest potential to lift the African continent out of poverty and alleviate hunger. Among the countries in sub-Saharan Africa, Tanzania has an abundance of natural resources and major agricultural potential. However, one of the most important constraints facing Tanzania's agricultural sector is the dependence on unreliable and irregular weather, including rainfall. A strategy to cope with climate uncertainty in semi-arid regions is to proceed with the sowing of the crop before the onset of the rainy season. The advantage is that when the rains start, seeds are already in the soil and can begin immediately the process of germination. The objective of this paper was to assess the effectiveness of dry-soil planting for maize as an adaptation strategy in the context of a changing climate in Dodoma, a semi-arid region in Tanzania. For this assessment, the DSSAT crop model was used in combination with climate scenarios based on representative concentration pathways. A probability of crop failure of more than $80 \%$ can be expected when sowing occurs during the planting window (of 21 days) starting on 1st November. The next planting window we assessed, starting on 23rd November (which was still before the onset of rain), presented significantly lower probabilities of crop failure, indicating that sowing before the onset of the rainy season is a suitable adaptation strategy. Results also indicated that, despite not reaching the highest maize grain yields, fields prepared for dry-soil planting still produced adequate yields. The cultivation of several fields using the dry planting method is a strategy farmers can use to cope with low rainfall conditions, since it increases the chances of harvesting at least some of the cultivated fields. We conclude that dry-soil planting is a feasible and valid technique, even in scenarios of climate change, in order to provide acceptable maize yields in semi-arid Tanzania.
\end{abstract}

Keywords DSSAT $\cdot$ Sub-Saharan region $\cdot$ Maize yield $\cdot$ Seed germination $\cdot$ Sowing date $\cdot$ Food security

Marcos A. Lana

marcos.lana@slu.se; lana@zalf.de

Ana Carolina F. Vasconcelos

ana3carol@yahoo.com.br

Christoph Gornott

gornott@pik-potsdam.de

Angela Schaffert

a.schaffert@uni-hohenheim.de

Michelle Bonatti

michebonatti@gmail.com

Johanna Volk

jo1994hannav@zedat.fu-berlin.de

Frieder Graef

graef@zalf.de
Kurt Christian Kersebaum

kersebaum@zalf.de

Stefan Sieber

stefan.sieber@zalf.de

1 Swedish University of Agricultural Sciences (SLU), Ulls väg 16, 75007 Uppsala, Sweden

2 Leibniz Centre for Agricultural Landscape Research (ZALF), Müncheberg, Germany

3 Federal University of Campina Grande, Campina Grande, Brazil

4 Potsdam Institute for Climate Impact Research (PIK), Potsdam, Germany

5 Hohenheim University, Hohenheim, Germany

6 Freie Universität Berlin, Berlin, Germany 


\section{Introduction}

Agriculture has the greatest potential to lift Africa out of poverty and to alleviate hunger. Given the nature of African agriculture, where a large proportion of farmers are smallholders and subsistence-based, it is essential to invest in and develop accessibility to quality inputs, markets for produce, good soils and soil management techniques, innovative finance tools and other resources that are needed for sustained agricultural production (Graef et al. 2017).

The agricultural sector in Tanzania is hampered by low productivity, poor infrastructure, and a lack of technology, being dominated by smallholder farmers cultivating average farm sizes of between 0.9 ha and 3.0 ha. About $70 \%$ of Tanzania's crop area is cultivated by hand hoe, $20 \%$ by ox plough and $10 \%$ by tractor, and almost all is rain fed. The production of food crops dominates the agricultural economy (KPMG 2015).

This background was confirmed in an extensive survey carried out in Tanzania by the Trans-SEC Project (Innovating Strategies to Safeguard Food Security using Technology and Knowledge Transfer: A People-Centred Approach) (Below et al. 2015; Graef et al. 2014, 2017; Löhr et al. 2016; Mutabazi et al. 2015). The major constraints facing the Tanzanian agricultural sector are the reduction in the available labor force, low land productivity due to the application of poor technologies, and dependence on unreliable and irregular weather (Mmbaga and Lyamchai 2002). Both crops and livestock are adversely affected by periodic droughts. Irrigation holds the key to stabilizing agricultural production in Tanzania, to improving food security, increasing the productivity and incomes of farmers, and producing higher valued crops such as vegetables and flowers (Evans et al. 2012). However, some other barriers to improve local food production and security are not directly tied to a lack of irrigation, but are related to the availability of farm credit, access to seeds and fertilizers, quality of seeds, farm implements and market reliability (Mdemu et al. 2017).

One of the major uncertainties with the future trajectory of agricultural productivity in Africa is the likely impact of a changing climate (IPCC et al. 2007). Several studies (Kurukulasuriya et al. 2006; Lesch et al. 2005; Nelson et al. 2010; Seo et al. 2009; Thornton et al. 2006) provide strong evidence that predicted changes in temperature and rainfall caused by global warming may impose additional serious constraints on agriculture in Africa (Benin et al. 2016). Climate change will have a direct impact on the availability of water for irrigated crops. In addition to changes with precipitation, climate-change-induced higher temperatures increase the water requirements of crops (Nelson et al. 2009).

Climate change is likely to make matters worse with further increases in rainfall variability being predicted (Agrawala et al. 2003; Schlenker and Lobell 2010). Climate change is also expected to alter pest and disease outbreaks, increase the frequency and severity of droughts and floods, and increase the likelihood of poor yields, crop failure and livestock mortality (Harvey et al. 2014). The ability of agricultural communities and other agricultural stakeholders in sub-Saharan Africa to cope with the constraints and opportunities of current climate variability must first be enhanced in order to be able to adapt to climate change and the predicted future increase in climatic variability. Tools and approaches are now available that allow for a better understanding, characterization and mapping of the agricultural implications of climate variability and the development of climate risk management strategies specifically tailored to the needs of stakeholders (Cooper et al. 2008).

Specific concerns about climate variability include variability in the onset and cessation of rainfall, rainfall amount, and frequency and duration of periods of soil water deficits. This variability greatly affects crop yield in rainfed systems, and is a major disincentive to the adoption of yield-improving practices, which then challenges researchers to develop adoptable practices and varieties. Therefore, knowledge of the seasonal climate variability and its associated risks is important to the improvement of crop management (Liben et al. 2015).

The shifting of planting date based on cultivar properties could prevent critical stages of crop development from coinciding with periods of extreme high temperature and water deficit, consequently helping to reduce yield loss from climate change (Tao and Zhang 2010). Generally, crop yields may suffer substantially with either a late onset or early cessation of the growing season. Shifting of planting date ensures that the seed, once in the soil, has sufficient moisture to trigger the germination process and further crop development. However, in order to be successful and effective this strategy needs the farmers to be available all the time before the expected onset of rainfall (Mugalavai et al. 2008).

Under the conditions observed in rural communities of Tanzania, especially in the semi-arid regions, farmers usually farm several field areas, sometimes many kilometers apart; the principle behind this is to take advantage of better soils and reduce the risk of total crop failure associated with the smallscale spatial distribution of precipitation. To be able to use fields in different areas, waiting for the onset of rainfall is not an adequate strategy. Therefore, farmers often practice so-called 'dry soil planting', when they seed the crop into dry soil a few days before the expected start of the rainy season (KPMG 2015). The advantage of this practice is that when the rainfall starts seeds are already in the soil and can immediately start to germinate. This is especially important in regions where the rainy season is not long enough to provide adequate moisture during the whole cropping cycle.

As an example, according to Liwenga (2008), in Mvumi, Tanzania, planting activities are normally carried out some two to three weeks before the expected time for the onset of the rains; in that study villagers explained that early planting is 
done prior to the onset of the rains so that crops could benefit from all of the moisture provided during the short rainy season. The same author, citing Holtland (1994), explains that seedlings make optimal use of the natural nitrogen $(\mathrm{N})$-flush that occurs after the first rain-showers. As $\mathrm{N}$ availability is, after water, the greatest constraint to cultivation in the Dodoma region, the difference between dry planting and planting a week after the onset of the rains can be considerable.

Nevertheless, despite the advantage of a faster start, planting into dry soil also poses the risk that germination is initiated by a precipitation event that is not the start of a rainy season. In this situation, the crop can start to germinate but then die during subsequent drying of the soil and seedling. In other situations there is also a risk that if the seed stays for a long period in the soil without sufficient moisture to trigger germination, high temperatures can cause loss of vigor, or it can be damaged or eaten by insects or other animals (Benin et al. 2016; Cooper et al. 2008).

In addition to planting dry seeds, seeds can be 'primed' with water, an enhancement method that might improve seed performance under stress conditions such as drought or when freshly harvested or aged seeds are used which might fail to germinate (Lutts et al. 2016). Harris et al. (1999) demonstrated how simple soaking seeds in water before sowing can increase the speed of germination and emergence, leading to better crop stands, and allow seedlings to grow much more vigorously. Some farmers in Zimbabwe already have experience of soaking maize and sorghum seeds in water before sowing, in an attempt to improve establishment, but the practice appears to be neither widespread nor regularly followed, probably because farmers need the opportunity to experiment for themselves; to do their own research and development (Harris et al. 2001).

Maize is the staple food for the majority of Tanzanians, providing about $60 \%$ of Tanzanian's dietary calories and $50 \%$ of the protein. With about five million ha, Tanzania has the largest planted area of maize in all Southern and East Africa. Maize production has significantly increased over the past 10 years, largely through expansion of area planted rather than increased grain yields. Over the past 50 years, maize production has kept pace with the increase in population (FAOSTAT 2016).

Most maize $(80 \%)$ is produced by small-scale farmers and is grown both for subsistence and as a cash crop. Between $65 \%$ and $80 \%$ of all maize is consumed within the producing households: only $20 \%$ to $35 \%$ enters commercial channels. Maize comprises an average of $16 \%$ of national household food expenditures, though there are big regional variations. The choice to grow maize, even in areas of insufficient rainfall, is driven by a strong dietary preference for maize over the more drought-adapted traditional cereals such as sorghum and millets. Efforts are being made to develop more drought tolerant cultivars of maize available to Tanzanian farmers and to increase irrigation (Doebley et al. 2010).

Most maize production in Tanzania is under low-input rainfed conditions. Simple hand hoes, farm-recycled seed, little use of synthetic fertilizers or agrochemicals and minimal weeding are the usual technologies and inputs employed. Maize crops frequently fail because of insufficient soil moisture. Irrigation is not usually available or selected as an option for maize, and on-farm water harvesting techniques are not yet well known or used (Wilson and Lewis 2015).

Drought is a major threat to maize in many parts of Tanzania. Maize production can be a risky and unreliable business because of erratic rainfall and the high susceptibility of maize to drought, while the performance of local droughttolerant cultivars is poor (Mmbaga and Lyamchai 2002). Erratic rainfall is making maize farmers in Tanzania vulnerable to low yields, which translates to food insecurity. Tanzania suffered the effects of a prolonged drought in the recent years (Doebley et al. 2010). These observations agree with the information gathered from farmers in the region during a comprehensive survey about many aspects of food security in the region (see Trans-SEC: Innovating Strategies to Safeguard Food Security using Technology and Knowledge Transfer: A People-Centred Approach - www.trans-sec.org).

In order to assess and understand the effects of climate change, crop models can be a useful tool to assess the influence of climatic and other environmental or management factors on crop development and yield (Reidsma et al. 2010). The Decision Support System for Agrotechnology Transfer DSSAT v. 4.5 contains the Crop System Model CERES Maize model (Jones et al. 2003) and can help to a) determine best planting dates, b) define fertilizer timing and amounts, c) support precision agriculture and d) detect/investigate potential impacts of climate change on agriculture. In the embedded CERES - Maize model, the development and growth of the crop is simulated on a daily basis from planting until physiological maturity. The model calculations are based on environmental and physiological processes that control the phenology and dry matter accumulation in different organs of the plant. The DSSAT also has other embedded models that can simulate the flow of nutrients and water balance in the soil. Despite the complex array of processes simulated by the crop model, some important processes such as effects of pests and diseases are still not well depicted (Donatelli et al. 2017), as are the impact of extreme events such as floods and hail (Alexandrov and Hoogenboom 2000) or high temperatures (above $35^{\circ} \mathrm{C}$ ) during anthesis, which reduces pollen viability (Porter and Semenov 2005).

Considering that smallholder farmers in Tanzania cultivate several fields at the same time, of which only some may be under a dry-soil planting management system, it can be expected that dry-soil planting is and will still be part of the 
strategies to reduce the risk of crop losses and help ensure food security in the context of a changing climate. Based on that, the objective of this paper was to assess the effectiveness of dry-soil maize planting as an adaptation strategy in a semiarid region of Tanzania. This assessment was done using a calibrated CERES - Maize crop model and tested different climate scenarios for the 2020-2059 and 2060-2099 periods.

\section{Methodology}

\subsection{Location}

Our assessment was done for the Dodoma region of Tanzania, as part of the activities of the Trans-SEC Project (see Graef et al. 2017). The study region lies between latitudes $5^{\circ} 50^{\prime} \mathrm{S}$ to $6^{\circ} 10^{\prime} \mathrm{S}$ and between longitudes $35^{\circ} 40^{\prime} \mathrm{E}$ to $36^{\circ} 05^{\prime} \mathrm{E}$, at an elevation of $1020 \mathrm{~m}$ above sea level. The dominant soil of the target region is defined as a ferralic Cambisol (FAO), which is low in fertility and seasonally waterlogged or flooded (Msongaleli et al. 2015). Detailed information about the soil used in this assessment is presented in Table 1. The area is characterized by low and erratic rainfall with a unimodal rainfall regime. The long-term mean annual rainfall is about $511 \mathrm{~mm}$ with average temperatures of $22.7^{\circ} \mathrm{C}$ (Fig. 1). The onset of rainfall usually occurs in early-mid December, and the rainy season extends until April. As the rainfall pattern in the study region is variable within the rainy season, maize cultivation is restricted to areas where water availability is higher and the soil has a higher water holding capacity.

\subsection{Climate scenarios}

Data for future climate scenarios are available from the InterSectoral Impact Model Intercomparison Project - ISI-MIP (Warszawski et al. 2014) as a bias-corrected dataset with daily values for temperature (Tmax, Tavg, Tmin), precipitation, relative humidity, and solar radiation. These data are well accepted and also used for the Agricultural Model Intercomparison and Improvement Project - AgMIP (Rosenzweig et al. 2013). The selected Representative Concentration Pathways (RCPs) for our study were the high-emission scenario RCP8.5, the medium-low-emission scenario RCP4.5 and the lowemission scenario RCP2.6 scenario (Moss et al. 2010). For each RCP scenario, five different projections (model-derived estimates of future climate) were used, as follows: GFDLESM2M (Dunne et al. 2013), HadGEM2-ES (Johns et al. 2006), IPSL-CM5A-LR (Hourdin et al. 2013), MIROCESM.CHEM (Watanabe et al. 2011), and NorESM1-M (Iversen et al. 2012), totaling 15 different projections of three RCPs. All the models have the added capability of explicitly representing biogeochemical processes that interact with physical-climate processes. To capture the fertilization effect of increasing levels of atmospheric $\mathrm{CO}_{2}$ (Long et al. 2006; Tubiello et al. 2007), the concentration of $\mathrm{CO}_{2}$ was adjusted yearly according to the respective RCP (Meinshausen et al. 2011).

\subsection{Crop modeling}

To generate projections of maize yield and assess the impact of weather scenarios and dry-seed planting management, a crop simulation model was employed. The crop modeling process was done using DSSAT (Jones et al. 2003), an established crop model already used in several impact assessment studies (Rivington and Koo 2011).

The maize cultivar used in this study was a locally adapted, open pollinated cultivar called Situka, with a yield potential at around $4 \mathrm{tha}^{-1}$ in Dodoma (according to reports from local technicians), and commonly cultivated by local farmers because of its early maturity and tolerance to low levels of soil nitrogen $(\mathrm{N})$, a typical condition of the study area (Msongaleli et al. 2015). This cultivar was already calibrated and validated for DSSAT (Mourice et al. 2014a, b) for Morogoro, situated $250 \mathrm{~km}$ east from Dodoma, where it can reach yields of $6.6 \mathrm{t}$ $\mathrm{ha}^{-1}$. However, for this study, a further validation step was done using three years of field data including soil, weather, agronomic management and yield (Kimaro et al. 2008, 2009)

Table 1 Soil profile parameters of the study region in Dodoma, Tanzania, indicating physical and chemical parameters for different soil depths

\begin{tabular}{|c|c|c|c|c|c|c|c|c|c|}
\hline $\begin{array}{l}\text { Layer } \\
\text { depth } \\
\mathrm{cm}\end{array}$ & $\begin{array}{l}\text { Clay } \\
\%\end{array}$ & $\begin{array}{l}\text { Silt } \\
\%\end{array}$ & $\begin{array}{l}\text { Organic } \\
\text { carbon } \\
\%\end{array}$ & $\mathrm{pH}$ in water & $\begin{array}{l}\text { Cation exchange } \\
\text { capacity } \\
\mathrm{cmol} / \mathrm{kg}\end{array}$ & $\begin{array}{l}\text { Total } \\
\text { nitrogen } \\
\%\end{array}$ & $\begin{array}{l}\text { Lower limit } \\
(\mathrm{LL}) \\
\mathrm{cm}_{3} / \mathrm{cm}_{3}\end{array}$ & $\begin{array}{l}\text { Drained upper } \\
\text { (DUL) } \\
\mathrm{cm}_{3} / \mathrm{cm}_{3}\end{array}$ & $\begin{array}{l}\text { Saturation } \\
(\mathrm{SAT}) \\
\mathrm{cm}_{3} / \mathrm{cm}_{3}\end{array}$ \\
\hline 15 & 19 & 5 & 0.41 & 4.8 & 6 & 0.07 & 0.122 & 0.188 & 0.375 \\
\hline 30 & 20 & 4 & 0.31 & 4.6 & 8.2 & 0.06 & 0.121 & 0.181 & 0.366 \\
\hline 45 & 23 & 4 & 0.23 & 4.5 & 9.2 & 0.12 & 0.145 & 0.206 & 0.366 \\
\hline 60 & 25 & 5 & 0.14 & 4.5 & 10.2 & 0.05 & 0.145 & 0.205 & 0.361 \\
\hline 75 & 34 & 2 & 0.14 & 4.6 & 10 & 0.05 & 0.190 & 0.249 & 0.364 \\
\hline 105 & 30 & 4 & 0.06 & 4.6 & 6 & 0.04 & 0.166 & 0.227 & 0367 \\
\hline
\end{tabular}


a

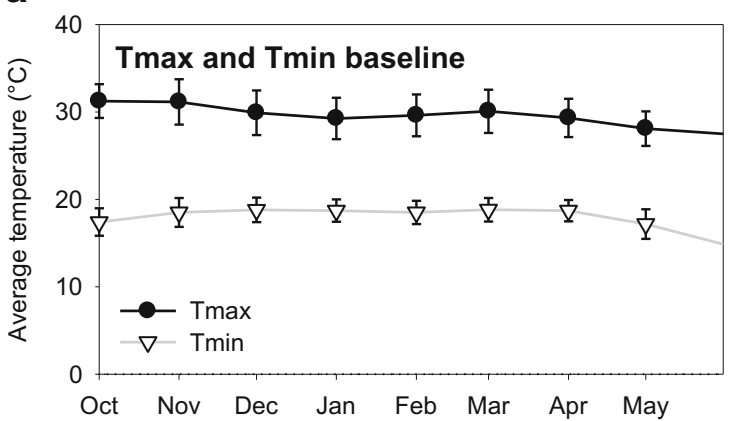

b

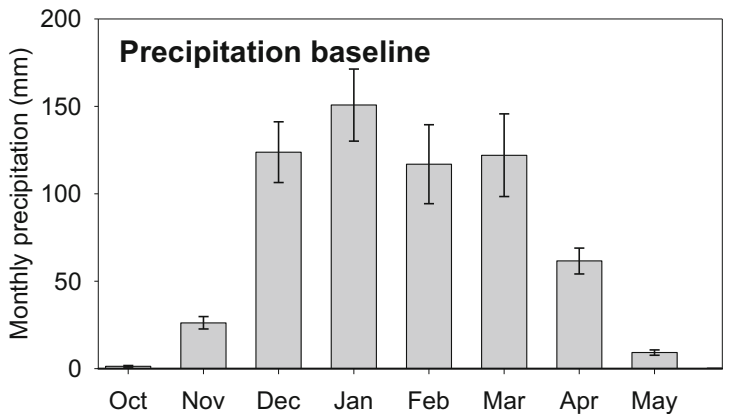

Fig. 1 Averages of (a) maximal and minimal monthly temperatures $\left({ }^{\circ} \mathrm{C}\right.$ ) and (b) monthly precipitation (mm) for the study site in Dodoma, Tanzania, during the crop season (data refer to the 2000-2015 period). Bars indicate the monthly standard deviation of each parameter

from research experiments conducted in nearby villages to confirm the ability of the model to simulate past observations in the study region. Difference-based indices such as mean bias error (MBE) (Addiscott and Whitmore 1987), mean percentage error (MPE), root mean squared error (RMSE) (Fox 1981) and relative root mean squared error (RRMSE) (Jørgensen et al. 1986) were used to evaluate the simulation outputs. The final maize plant population density was defined at 33000 plants per ha, planted at $7 \mathrm{~cm}$ depth in rows with $75 \mathrm{~cm}$ spacing between rows. This low plant population density, the space between rows and planting depth represent the common practices in the region. Fertilizer use was set to $2000 \mathrm{~kg} \mathrm{ha}^{-1}$ of dry cattle manure, equivalent to $40 \mathrm{~kg} \mathrm{ha}^{-1}$ $\mathrm{N}$, to be applied on the day of planting. No irrigation was applied. DSSAT was instructed to start the simulations on 1 January each year to provide a more realistic soil water balance at sowing. For planting dates taking place after 1 January, the simulation started on 1 January of the previous year. Harvest was set to take place two weeks after physiological maturity, as calculated by the model. The format of climate scenario files was adjusted for DSSAT structure using the Weatherman software (Wilkens et al. 2004). Simulations were run for each projection and RCP. For the analysis of results, yields generated with different projections were merged in ensembles (according RCP) in order to provide more robust information (Randall and Wood 2007).

\subsection{Adaptation strategies}

Initially, in order to establish a yield baseline, simulations using all the RCPs were run for the 2000-2015 period using the different planting windows (described in the next paragraph), starting on 1 st of November and at every 21 days, until 1st of February, totaling seven planting windows. The objective was to verify if the simulations could mimic the best planting window (mid-December) and crop management as informed by the local farmers and technicians involved in the Trans-SEC project. Yields from the same planting window were averaged to identify the one with the highest yields (best planting date). Once the best planting window was defined for the baseline period, the next step was to run simulations using this planting window for the 2020-2059 and the 2060-2099 periods.

In order to mimic the actual practice in the region of dry soil planting (that means that farmers plant the seeds into dry soil and wait for rainfall onset within 21 days), five planting windows (each of 21 days) were defined, starting on 1 November. The assumptions were that 1 ) in the dry soil planting systems the seed would remain viable for 21 days and initiate the germination process only if the soil moisture of the top $20 \mathrm{~cm}$ reached at least $30 \%$ of the soil field capacity, and that 2) based on soil texture and soil bulk density the soil module embedded in the crop model was able to correctly simulate the soil moisture. Although maize seed can absorb moisture from the soil even when soil moisture conditions are far below permanent wilting point (Muthukuda Arachchi et al. 1999), the minimum external water potential permitting maize germination observed by Hunter and Erickson (1952) was shown to be $-1.25 \mathrm{MPa}$. The same authors reported that maize seed started to germinate only when seed moisture exceeded the critical value of $30.5 \%$ of field capacity. If during the planting window the critical soil moisture was not reached, it is assumed that the seeds wereno longer in a condition to germinate, and the yield was set to zero. If germination starts, but a dry spell kills the seedling (crop abortion) or the crop produces less than $400 \mathrm{~kg} \mathrm{ha}^{-1}$ of grain, then the crop season was considered lost (crop failure).

\section{Results}

\subsection{Model and cultivar validation}

As the crop model and the Situka cultivar were already validated for a different region of Tanzania (Mourice et al. $2014 a, b)$, but not for a nearby location, a second validation was considered necessary. Simulations using the same conditions (real data for weather, soil, agronomic management) 
of the field experiments done by Kimaro et al. $(2008,2009)$ including a nearby region, were done. The results of the validation were satisfactory, indicating that the model could mimic maize grain yields from field observations of three available crop seasons (2004-2006), as presented in Table 2. As the MBE term describes the direction of the error bias, the positive value of $160 \mathrm{~kg} \mathrm{ha}^{-1}$ indicates that the predictions were overestimated (in absolute values) compared to the observations. If all simulated and observed values are the same, then MBE, MPE, RMSE and RRMSE should be equal to zero. Overall, the results certified that the model could adequately mimic field observations for maize yield. Nevertheless, it is important to emphasize that the experiments used to generate these observations were village-level research experiments, and not data gathered from maize crops on smallholder farm fields, where yields are probably often lower. Data related to phenology and above ground biomass were not available for comparison in this exercise.

\subsection{Definition of best actual planting dates}

Simulations run for the 2000-2015 period using the data for the RCPs identified the planting windows beginning on the dates 12 December and 6 January as the ones with the highest grain yields (Fig. 2). This coincided with the onset of the rainy season as reported by the local farmers from the study sites (Fig. 1).

\subsection{Climate change scenarios}

For Tanzania, and in particular for the Dodoma region, the RCP's showed slight changes in the precipitation amount during the crop season (Fig. 3). No significant shift in the onset of the rainy season was identified for the study region. For the 2020-2059 period, the scenarios indicated a stability or reduction in accumulated precipitation until February-March (using the 2000-2015 period as baseline). For the rest of the crop

Table 2 Results of the validation process for the DSSAT crop simulation model using difference-based indices comparing simulated and field observations of grain yields from maize cv. Situka in three different seasons (2004-2006) in Tanzania. MBE: mean bias error; MPE: mean percentage error; RMSE: root mean squared error; RRMSE: relative root mean squared error

\begin{tabular}{lllllll}
\hline Year & \multicolumn{2}{l}{ Yield $\left({\left.\mathrm{Kg} . h a^{-1}\right)}^{n}\right.$} & MBE & MPE & RMSE & RRMSE \\
\cline { 2 - 6 } & Observed & Simulated & Kg.ha $^{-1}$ & $\%$ & Kg.ha $^{-1}$ & $\%$ \\
\hline 2004 & 2504 & 2491 & 158 & 8 & 204 & 9.7 \\
2005 & 1900 & 2093 & & & & \\
2006 & 1901 & 2196 & & & & \\
\hline
\end{tabular}

$M B E$, Mean Bias Error; $M P E$, Mean percentage error; RMSE, Root Mean Squared Error; RRMSE, Relative Root Mean Squared Error

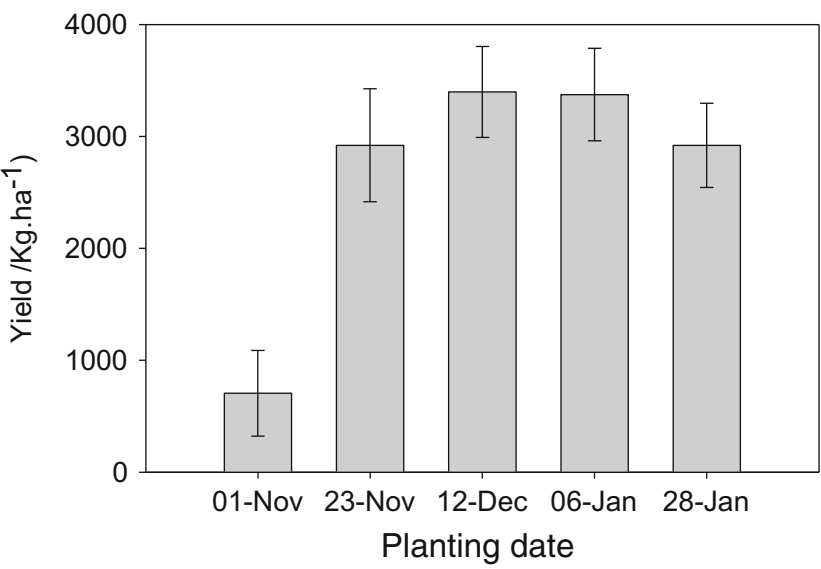

Fig. 2 Assessment of best maize planting dates according to grain yield using the Ceres maize model for the 2000-2015 period (referred to as baseline) in the study site in Dodoma, Tanzania. Bars represent the standard deviation of yield

season, the RCPs tended to deviate in terms of accumulated precipitation. For the second period (2060-2099), the models projected a slight reduction in accumulated rainfall at the beginning of the cropping season, with later increments in precipitation in the 4.5 and $8.5 \mathrm{RCPs}$. In contrast to projections for other regions of the world, the precipitation pattern in Tanzania should not change its timing, especially for the first period (2020-2059). In terms of the amount of rainfall, the 4.5 and $8.5 \mathrm{RCPs}$ indicated an increase in precipitation volume for the later period (2060-2099), when compared to the baseline (Fig. 3b), while the RCP 2.6 indicated a reduction in accumulated precipitation.

For air temperature (Fig. 4), all RCP's indicated an increment for Tmax and Tmin. For the first time slice, the three RCPs showed relatively similar increments in both Tmax and Tmin. For the 2060-2099 period, there was a clear distinction between the different RCPs, with the highest increase observed for the RCP 8.5 , followed by the RCP 4.5 and finally the RCP 2.6 .

\subsection{Impact assessment with the use of dry soil planting}

When using dry-soil planting as a strategy to make possible the cultivation of several different fields per farm, we assessed that the very early dry soil planting window (starting date 1 November) for both time periods (2020-2059 and 2060 2099) presented more than an $80 \%$ probability of failure for all RCPs, while the next planting windows reduced the probability of failure to less than $20 \%$ (Fig. 5a and b). In the best situation, when planting occurs near mid-December, the chances of losses from crop failure are very low. The dry soil planting practice in the selected region can only be said to occur when done before mid-December. After this planting window, with the very likely onset of the rainy season, sowing will take place into already wet soil. 


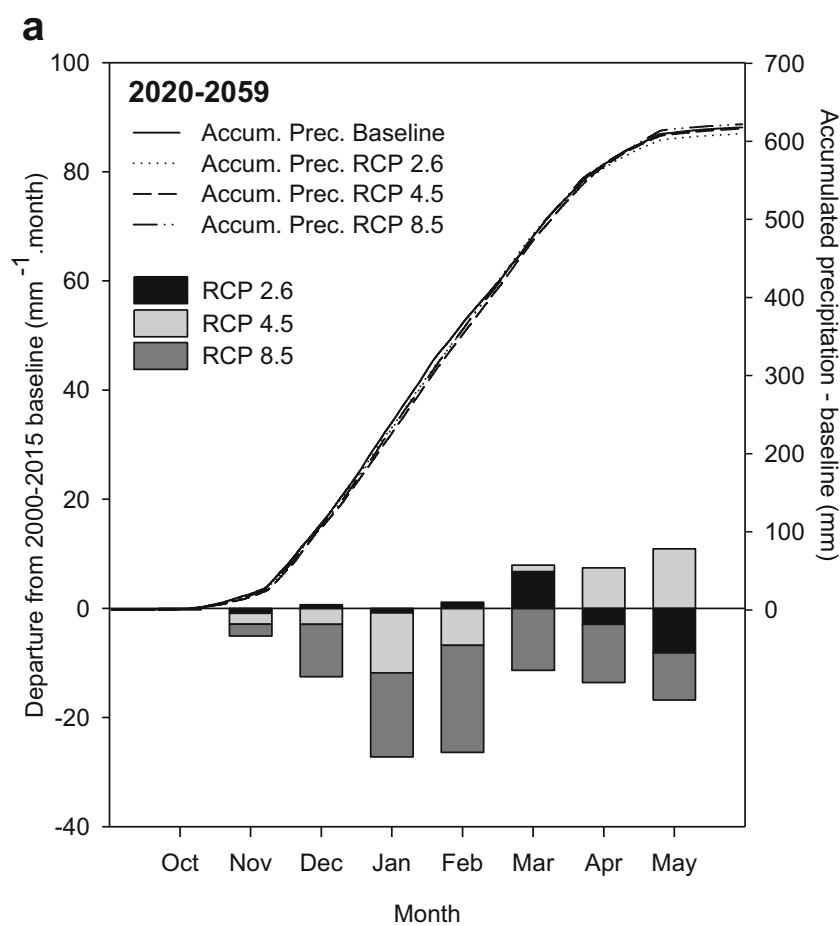

Fig. 3 Modelled accumulated precipitation along the cropping season in Dodoma, Tanzania represented by the 2000-2015 baseline (solid line) compared to different representative concentration pathways (RCPs)

Dry-seed planting is said to occur when the soil, at the time of sowing, has insufficient moisture to trigger germination, b

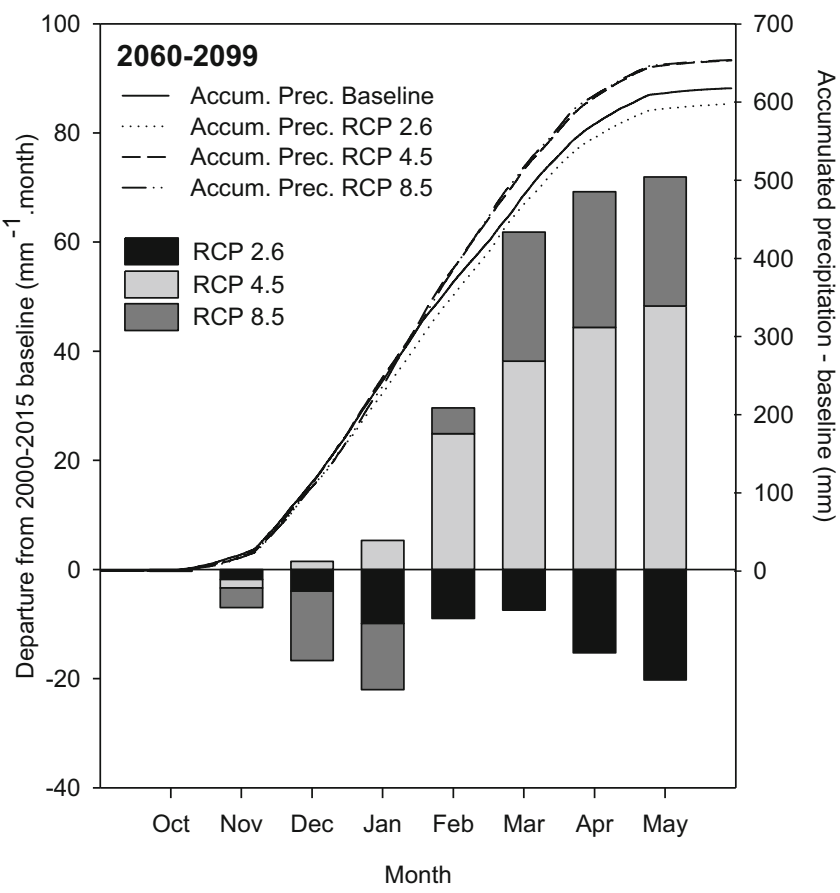

(dotted and dashed lines) for (a) 2020-2059 and (b) 2060-2099. Stacked bars represent the monthly accumulated precipitation departure from the baseline according different RCPs

which as seen in Fig. 6a and b, are planting windows starting on 1st of November and 23rd November. In many years, the
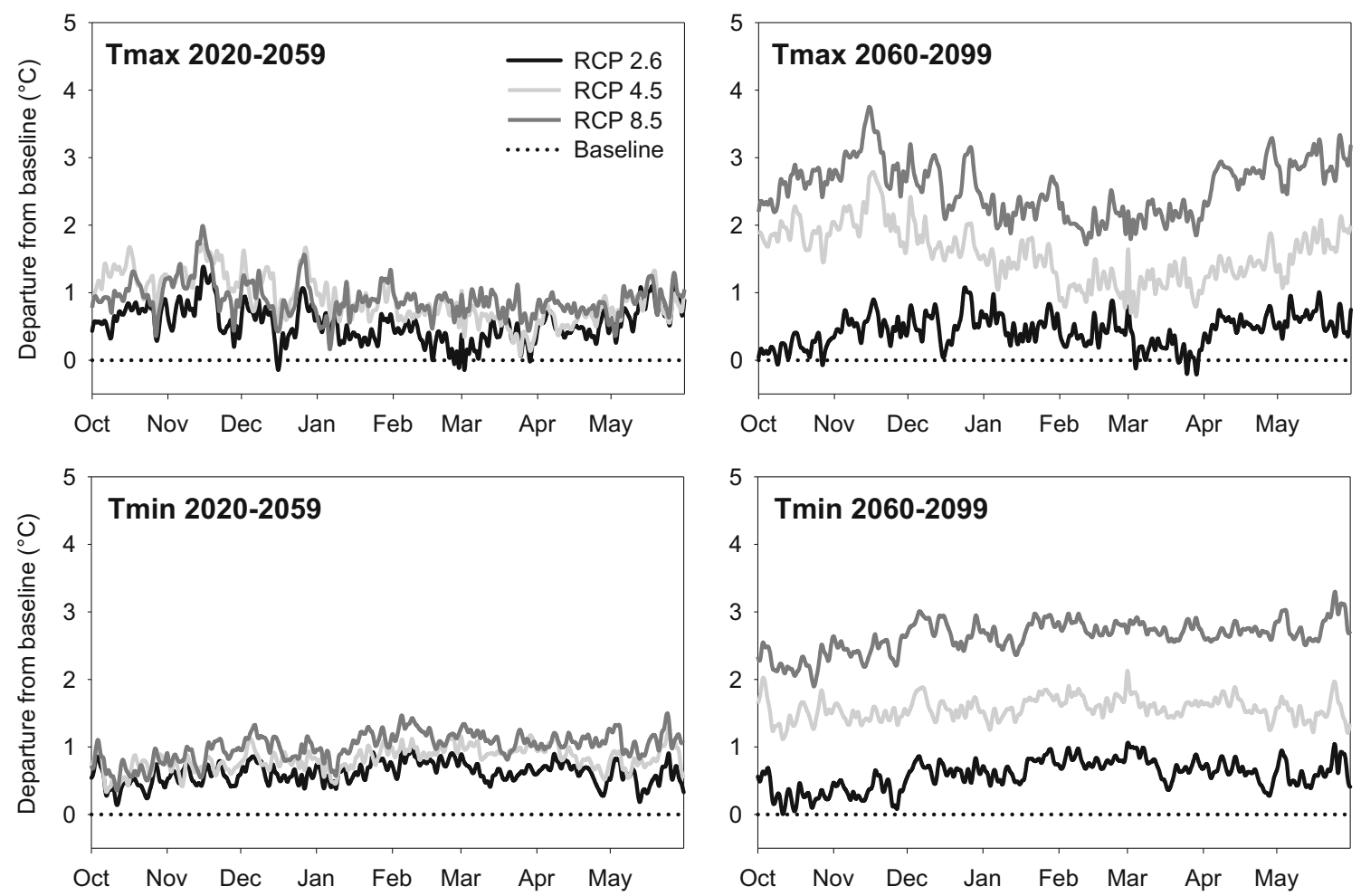

Fig. 4 Maximal (Tmax) and minimal (Tmin) temperature changes in Dodoma, Tanzania according different representative concentration pathways (RCPs) for two time periods (2020-2059 and 2060-2099). The dashed line represents the baseline relating to the 2000-2015 period 
a

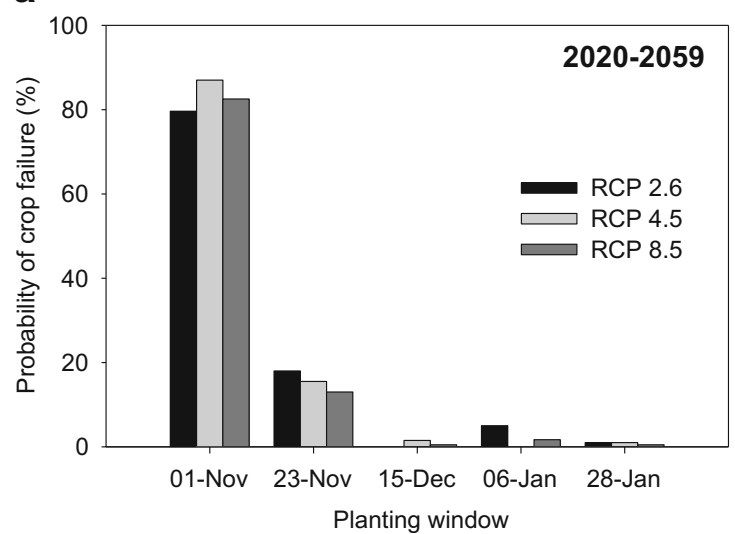

Fig. 5 Frequency of maize crop failure (defined as grain yields lower than $400 \mathrm{~kg} \mathrm{ha}^{-1}$ ) derived from all representative concentration pathways (RCPs) according different planting windows (each of 21 days) using dry

third planting window also does not meet the minimal soil moisture levels (30.5\% of field capacity) at the beginning, as seen by the high dispersion of symbols in Fig. 6 indicating the start of the germination process. By advancing the planting window, the start of germination tends to concentrate on or very close to the beginning of each planting window, because of sufficient soil moisture to trigger germination. Especially for the two last planting windows, in both time periods, we observed that for almost all RCPs and years, the soil already had enough moisture for immediate seed imbibition and the start of germination. This higher soil moisture availability at the planting time, however, does not automatically ensure good crop performance, as yield will also be defined by climatic events that occur well after germination.

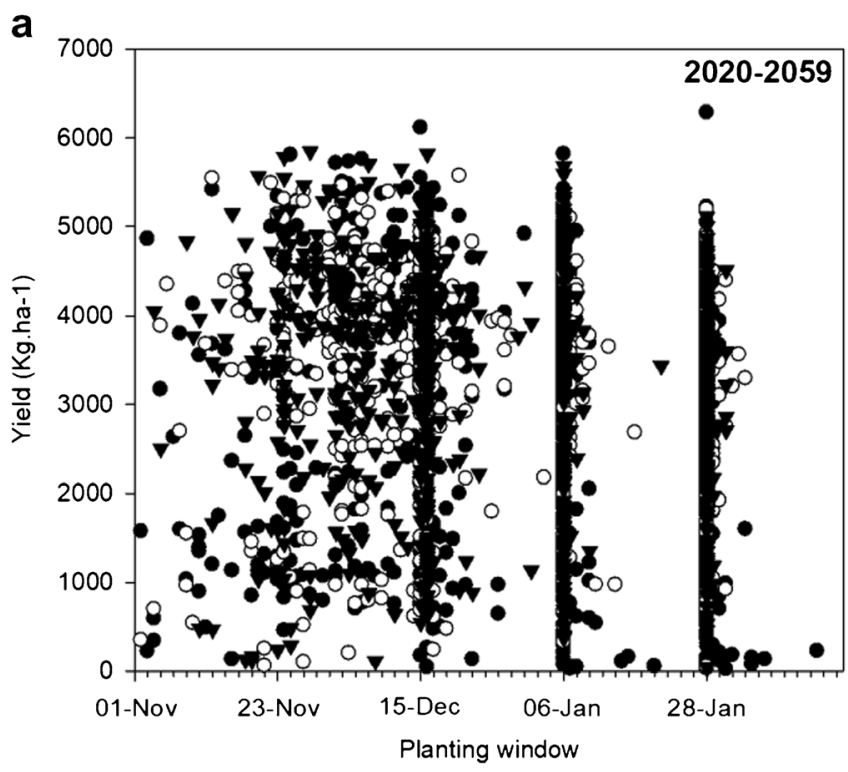

Fig. 6 Maize grain yields simulated by the DSSAT model using different scenario periods and different planting windows (dates in the $\mathrm{X}$ axis indicate the start of the planting window) using the dry soil planting adaptation strategy for Dodoma, Tanzania; (a) 2020-2059; (b) 2060- b

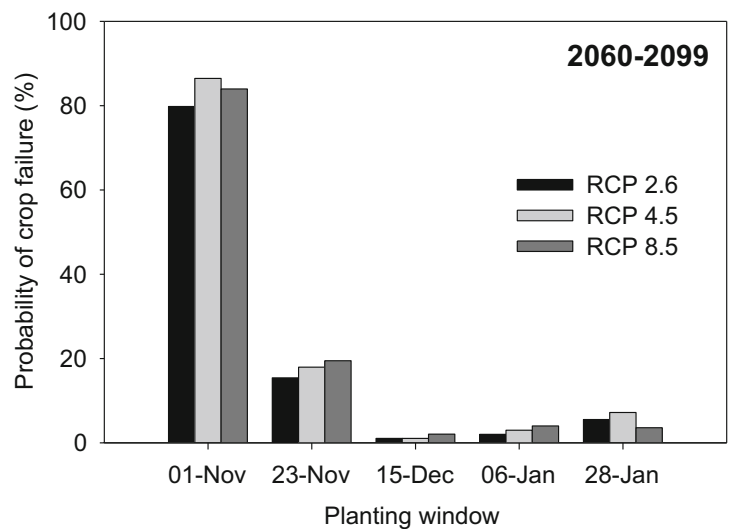

soil planting as a strategy in Dodoma, Tanzania. Values for the 2020-2059 period are on the left (a), while the 2060-2099 period are on the right (b). The date on the $\mathrm{x}$ axis indicates the start of the planting window

For maize grain yield, the most successful planting windows for both time slices were between 23 November and 6 January, as seen in Fig. 7. As yield is defined by several parameters, it is assumed that the above mentioned planting windows were the ones combining the best emergence conditions for the crop (soil moisture) as well as adequate water supply during the crop's growth cycle. Late planting date windows, despite the high values of initial soil moisture that allow for immediate germination, failed to provide an adequate amount of rainfall during the vegetative stages and especially during the reproductive stages of maize development, which occur towards the end of the rainy season. As seen in Fig. 3, precipitation ceases in April, when the plants that germinated during the latest planting times are expected to be in the grain

b

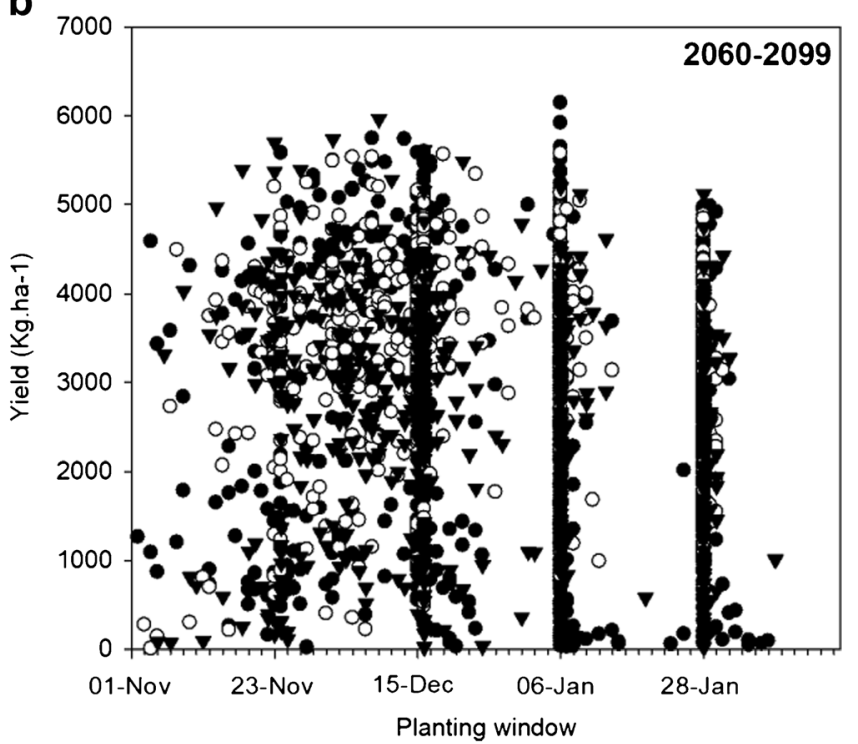

2099. The different representative concentration pathways (RCP's) are represented by $\circ(\mathrm{RCP} 2.6), \bullet(\mathrm{RCP} 4.5)$ and $\boldsymbol{\nabla}(\mathrm{RCP} 8.5)$ and indicate when the critical threshold of soil moisture for seed imbibition was reached 
a

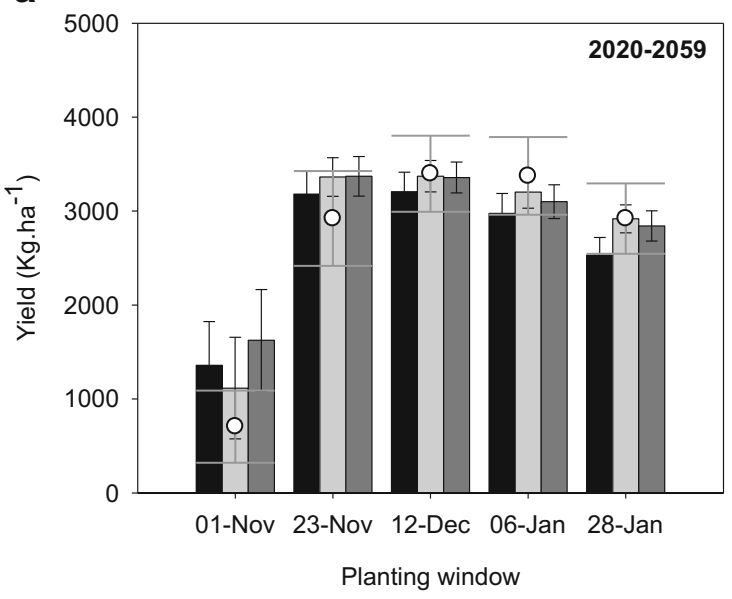

Fig. 7 Maize grain yields generated for different planting windows and representative concentration pathways (RCPs) in two time periods (slices): 2020-2059 (a) and 2060-2099 (b) for Dodoma region,

filling phase. Comparing the baseline yields (for 2000-2015) and projected yields for 2020-2099 from both time periods (slices) (Fig. 7), no large changes in yield were expected to occur under both time slices.

\section{Discussion}

In cropping systems reliant on rainfall as the sole source of moisture for crop growth, seasonal rainfall variability is inevitably mirrored in both highly variable crop production levels and in the risk-averse livelihood and coping strategies that have emerged over time in smallholder farming communities.

For this assessment, the Ceres crop model evaluation using the Situka maize cultivar was considered adequate since values of MPE and RRMSE are close to zero. This shows that, when input parameters are known, the model can properly mimic field observations such as the ones of Kimaro et al. $(2008,2009)$ used in this exercise for model evaluation. The RRMSE below $10 \%$ can be considered excellent, according Jamieson et al. (1991). The RMSE $\left(204 \mathrm{~kg} \mathrm{ha}^{-1}\right)$ provides the square root of the average of squared differences between prediction and actual observations, while the RRMSE indicates as a percentage how heterogeneous the simulation results are in relation to the observations. The difference between the MPE and the RRMSE (1.7\%) shows that, by using the RMSE as the base component, errors are magnified. Also a positive MBE is desirable, indicating that the model over-predicted yields, according Willmott (1982). Another aspect that supports the ability of the crop model to mimic field observations is that the simulations using weather scenarios for the period 2000-2015 matched the best planting dates reported by farmers in the study region.

For temperatures in East Africa, models project increments in surface air temperature over land between the end of the century (2070-2099) and the present day (1980-2010). Similarly, for b

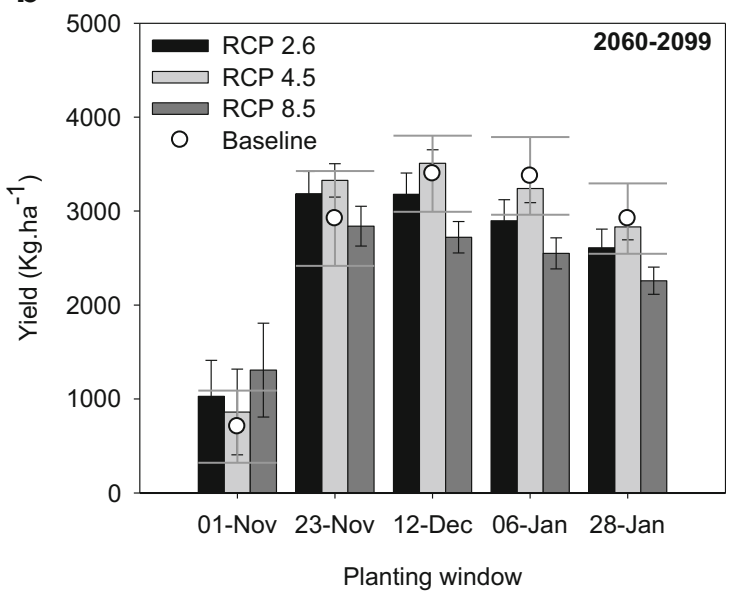

Tanzania. The baseline yield (2000-2015) is represented by the white circle symbol for each planting window in both time slices. Bars indicate the standard deviation

annual precipitation, all models indicate an increase of 5\% to $20 \%$ in precipitation (Warszawski et al. 2014). These different future climate scenarios allowed the 'mapping' of the uncertainty of impact assessments on crop yields and have already been used in several other assessments as listed by Müller et al. (2010), but with different levels of precision.

Despite the significant increases in temperature predicted for the later time period (slice) (2060-2099) (Fig. 4), these deleterious effects could be neutralized or partially reduced by the increment in precipitation (Fig. 3) observed in the middle of the cropping season. An increment in temperature will also accelerate the development of the crop, which may help to avoid the occurrence of the grain filling phase after the end of the rainy season. Additionally, the viability of maize pollen decreases with exposure to temperatures above $35^{\circ} \mathrm{C}$ (Dupuis and Dumas 1990), and this effect can be enhanced under high vapor pressure deficits (Hatfield and Prueger 2015). It is important to note that there is a differentiation between the RCPs only in the 2060 2099 period (Fig. 7b), when RCP 4.5 projected the highest yields. For this RCP, the significant increment in temperature was neutralized by the increment in accumulated precipitation.

Data from a field survey carried out by Mourice et al. (2014a, b) for the Wami Basin (which includes the study region) shows that reported yields of maize on smallholder farms range from $50 \mathrm{~kg} \mathrm{ha}^{-1}$ to $3600 \mathrm{~kg} \mathrm{~h}^{-1}$, with an average of only $860 \mathrm{~kg} \mathrm{ha}^{-1}$. The discrepancy observed between the yields from Table 2 (which originated from field experiment observations and simulations) and the ones reported above can be attribute to many factors, ranging from agronomic management (sowing date, plant population, fertilizer use, cultivar, irrigation), biophysical factors (soil type, soil compaction, fertility, water or temperature stress, attack of pests, weeds, diseases) to other problems such as animal grazing, theft and lodging. Specifically with regard to crop models an important aspect to be considered is that under field conditions crops will 
often be subjected to stressors that are not included or not simulated in the model (e.g. pests, diseases, and many others). As stated by Donatelli et al. (2017), this capability to fully model the farm situation is still missing in many crop models, although developments in recent decades are moving towards the quantitative description of the impact of pests and diseases on yield. Differences in management (cultivar, plant population, planting date and soil and nutrient management), soil and weather also contribute to increase this gap. Luhunga et al. (2017), using a fixed $\mathrm{CO}_{2}$ concentration of $360 \mathrm{ppm}$, also assessed the impacts of climate change scenarios on maize production in the Wami river basin of Tanzania using a single planting window of 15 days (1-15 December), reaching slightly lower baseline yields for maize. Both studies used the same maize cultivar (Situka), but without conducting a further calibration to verify the plausibility of the model for other regions, as recommended by Grassini et al. (2015). Since the region where the crop model was applied does have diverse environmental conditions, it is important to test, adjust, and validate model parameters as necessary.

Regarding dry-soil planting as an adaptation strategy, Akinnagbe and Irohibe (2014) reported that in Tanzania, to avoid crop production risks due to rainfall variability and drought, staggered planting into dry soil before the onset of rains is very common for many farmers. The cultivation of several fields using the dry planting method is therefore regarded as a special feature of adapting to low rainfall conditions since it increases the chances of harvesting at least some of the cultivated fields.

Another aspect that favors dry-soil planting as an ex-ante drought risk adaptation strategy to help ensure food security is to shift and extend the cultivation area to different fields (Westengen and Brysting 2014). The spatial diversification of fields is an effective ex-ante drought risk coping strategy that reduces exposure to risk (Shiferaw et al. 2014). Under such conditions, the risk of income shortfall is reduced by growing maize crops on several fields, and reduced even more when different crops are cultivated. According to Pandey et al. (2007), this principle is used in different types of diversification common in rural societies. Examples include the spatial diversification of farms, diversification of agricultural enterprises and diversification from farm to non-farm activities.

Although ex-ante strategies can be costly in terms of foregone opportunities for income gains because of the choice of safer but low-return activities by farmers, they might help with reducing fluctuations of income (Pandey et al. 2007) and can reduce food insecurity. Moreover, since the availability of labor is one of the major factors affecting the performance of agriculture, the cultivation of some plots before the rainy season maximizes labor efficiency. In this situation, farmers prepare and cultivate the most distant fields before the expected start of the rainy season (Graef and Haigis 2001), leaving the cultivation of the closest fields for the beginning of the rainy season.
Despite the potential to reduce crop losses and therefore to affect food security, the employment of dry-soil planting needs to be followed by other initiatives to reduce mining of soil nutrients (Bekunda et al. 2004), improvement of soil water retention potential, the reduction of soil erosion, diversification of crops, among others. Practices to design climatechange-resilient farming systems are comprehensively described by Altieri et al. (2015) and can foster the local food security by diluting the risk of total crop loss, reducing the variability in yields and ensuring a source of income.

\section{Conclusions}

Planting into dry soil is an important strategy for farmers managing several fields under circumstances of low water availability. The main advantage of this practice is the planting before the onset of the rainy season, while the main drawback is that a delay in the onset of the rainy season will increase the risk of a false start or crop failure.

For this impact assessment, a crop model (the Ceres model in DSSAT) was satisfactorily validated for a maize cultivar (Situka) in the Dodoma region of Tanzania, indicating its ability to respond to different planting dates and climate change scenarios.

The climate change scenarios did not indicate a considerable shifting in the onset and end of the rainy season, but changes in the accumulated precipitation during the cropping season were predicted for the 2060-2099 period. For temperature, an increment in maximum temperature during the cropping season for the 2020-2059 period of about $1{ }^{\circ} \mathrm{C}$ was predicted for all representative concentration pathways (RCP's), while for the 2060-2099 period increments ranged from $<1{ }^{\circ} \mathrm{C}$ to almost $3{ }^{\circ} \mathrm{C}$, depending on the RCP.

Regarding the probability of failure of the maize crop (yields $<400 \mathrm{~kg} \mathrm{ha}^{-1}$ ), early planting windows (beginning 1 November) presented up to an $85 \%$ chance of failure, with the lowest failure probability occurring with the 15 December planting window. The model simulation results indicated that fields prepared and sowed under the concept of dry-soil planting (no more than 21 days before the onset of the rainy season) had a considerably lower probability of crop failure for the two different tested periods (2020-2059 and 2060-2099).

We conclude that dry-soil planting is a feasible adaptation strategy for farmers to cultivate more fields with maize and therefore reduce the risks of food insecurity in the Dodoma region of Tanzania.

Acknowledgements All the activities related to this work were done with support of the Trans-SEC Project, sponsored by the German Federal Ministry of Education and Research (BMBF) and co-financed by the German Ministry for Economic Cooperation and Development (BMZ). The first author also expresses his gratitude to the MACSUR Knowledge HUB (CropM, C1). 


\section{Compliance with ethical standards}

Conflict of interest The authors declare that they have no conflict of interest.

Open Access This article is distributed under the terms of the Creative Commons Attribution 4.0 International License (http:// creativecommons.org/licenses/by/4.0/), which permits unrestricted use, distribution, and reproduction in any medium, provided you give appropriate credit to the original author(s) and the source, provide a link to the Creative Commons license, and indicate if changes were made.

\section{References}

Addiscott, T. M., \& Whitmore, A. P. (1987). Computer simulation of changes in soil mineral nitrogen and crop nitrogen during autumn, winter and spring. Journal of Agricultural Science, UK, 109, 141-157.

Agrawala, S., Moehner, A., Hemp, A., van Aalst, M., Hitz, S., Meena, H., et al. (2003). Development and climate change in Tanzania: focus on Mount Kilimanjaro. Paris, France.

Akinnagbe, O., \& Irohibe, I. J. (2014). Agricultural adaptation strategies to climate change impacts in Africa: a review. Bangladesh Journal of Agricultural Research, 39(3), 407-418.

Alexandrov, V. A., \& Hoogenboom, G. (2000). The impact of climate variability and change on crop yield in Bulgaria. Agricultural and Forest Meteorology 104(4):315-327

Altieri, M. A., Nicholls, C. I., Henao, A., \& Lana, M. A. (2015). Agroecology and the design of climate change-resilient farming systems. Agronomy for Sustainable Development, 35(3), 869-890.

Bekunda, M. A., Nkonya, E., Mugendi, D., \& Msaky, J. J. (2004). Soil fertility status, management, and research in East Africa. East African Journal of Rural Development, 20(1), 94-112.

Below, T. B., Schmid, J. C., \& Sieber, S. (2015). Farmers' knowledge and perception of climatic risks and options for climate change adaptation: a case study from two Tanzanian villages. Regional Environmental Change, 15(7), 1169-1180.

Benin, S., Wood, S., \& Nin-Pratt, A. (2016). Introduction. In Agricultural productivity in Africa: Trends, patterns, and determinants. In S. Benin (Ed.), Chapter 1. (pp. 1-23). Washington, DC: International Food Policy Research Institute (IFPRI). https://doi.org/10.2499/9780896298811_01.

Cooper, P. J. M., Dimes, J., Rao, K. P. C., Shapiro, B., Shiferaw, B., \& Twomlow, S. (2008). Coping better with current climatic variability in the rain-fed farming systems of sub-Saharan Africa: an essential first step in adapting to future climate change? Agriculture, Ecosystems and Environment, 126(1-2), 24-35.

Doebley, J. F., Iltis, H., Gates, R. N., Quarin, C. L., Stephen, L., Zubeda, M., et al. (2010). Mitigating the impact of drought in Tanzania : the WEMA intervention. African Journal of Agricultural Research, 9, 12.

Donatelli, M., Magarey, R. D., Bregaglio, S., Willocquet, L., Whish, J. P. M., \& Savary, S. (2017). Modelling the impacts of pests and diseases on agricultural systems. Agricultural Systems, 155, 213-224.

Dunne, J. P., John, J. G., Shevliakova, S., Stouffer, R. J., Krasting, J. P., Malyshev, S. L., et al. (2013). GFDL's ESM2 global coupled climate-carbon earth system models. Part II: carbon system formulation and baseline simulation characteristics. Journal of Climate, 26(7), 2247-2267.

Dupuis, I., \& Dumas, C. (1990). Influence of temperature stress on in vitro fertilization and heat shock protein synthesis in maize (Zea mays L.) reproductive tissues. Plant Physiology, 94(2), 665-670.

Evans, A. E. V, Giordano, M., \& Clayton, T. (2012). Investing in Agricultural Water Management to Benefit Smallholder Farmers in Ghana. IWMI Working Papers. https://doi.org/10.5337/2012.211
FAOSTAT. (2016). FAOSTAT. Food and Agriculture Organisation of the United Nations. http://www.fao.org/faostat/en/. Accessed 20 Dec 2015.

Fox, D. G. (1981). Judging air quality model performance. Bulletin of the American Meteorological Society. https://doi.org/10.1175/15200477(1981)062<0599:JAQMP>2.0.CO;2.

Graef, F., \& Haigis, J. (2001). Spatial and temporal rainfall variability in the Sahel and its effects on farmers' management strategies. Journal of Arid Environments, 48(2), 221-231.

Graef, F., Sieber, S., Mutabazi, K., Asch, F., Biesalski, H. K., Bitegeko, J., et al. (2014). Framework for participatory food security research in rural food value chains. Global Food Security, 3(1), 8-15.

Graef, F., Uckert, G., Schindler, J., König, H. J., Mbwana, H. A., et al. (2017). Expert-based ex-ante assessments of potential social, ecological, and economic impacts of upgrading strategies for improving food security in rural Tanzania using the ScalA-FS approach. Food Security. https://doi.org/10.1007/s12571-016-0639-x.

Grassini, P., van Bussel, L. G. J., Van Wart, J., Wolf, J., Claessens, L., Yang, H., et al. (2015). How good is good enough? Data requirements for reliable crop yield simulations and yield-gap analysis. Field Crops Research, 177, 49-63.

Harris, D., Joshi, A., Khan, P. A., Gothkar, P., \& Sodhi, P. S. (1999). Onfarm seed priming in semi-arid agriculture: Development and evaluation in maize, rice and chickpea in India using participatory methods. Experimental Agriculture, 35(1), 15-29.

Harris, D., Raghuwanshi, B. S., Gangwar, J. S., Singh, S. C., Joshi, K. D., Rashid, A., \& Hollington, P. A. (2001). Participatory evaluation by farmers of "on-farm" seed priming in wheat in India. Experimental Agriculture, 37(3), 403-415.

Harvey, C. A., Rakotobe, Z. L., Rao, N. S., Dave, R., Razafimahatratra, H., Rabarijohn, R. H., et al. (2014). Extreme vulnerability of smallholder farmers to agricultural risks and climate change in Madagascar. Philosophical Transactions of the Royal Society of London. Series B, Biological Sciences, 369(1639). https://doi.org/10.1098/rstb.2013.0089

Hatfield, J. L., \& Prueger, J. H. (2015). Temperature extremes: effect on plant growth and development. Weather and Climate Extremes, 10, 4-10.

Hotland, G. (1994) A farming systems analysis of Mvumi Division, Dodoma Region, Tanzania: A case study on intensifying agriculture in semi-arid Africa (pp. 131). Dodoma: Diocese of Central Tanganika.

Hourdin, F., Foujols, M. A., Codron, F., Guemas, V., Dufresne, J. L., Bony, S., et al. (2013). Impact of the LMDZ atmospheric grid configuration on the climate and sensitivity of the IPSL-CM5A coupled model. Climate Dynamics, 40(9-10), 2167-2192.

Hunter, J. R., \& Erickson, A. E. (1952). Relation of seed germination to soil moisture tension. Agronomy Journal, 44(3), 107-109.

IPCC, 2007: Climate Change 2007: Synthesis Report. In Core Writing Team, Pachauri, R. K \& Reisinger A. (Eds.), Contribution of Working Groups I, II and III to the Fourth Assessment Report of the Intergovernmental Panel on Climate Change (pp. 104). Geneva: IPCC.

Iversen, T., Bentsen, M., Bethke, I., Debernard, J. B., Kirkevåg, a., Seland, Ø., et al. (2012). The Norwegian Earth System Model, NorESM1-M - Part 2: Climate response and scenario projections. Geoscientific Model Development Discussions, 5(3), 2933-2998.

Jamieson, P. D., Porter, J. R., \& Wilson, D. R. (1991). A test of the computer simulation model ARCWHEAT1 on wheat crops grown in New Zealand. Field Crops Research, 27(4), 337-350.

Johns, T. C., Durman, C. F., Banks, H. T., Roberts, M. J., McLaren, A. J., Ridley, J. K., et al. (2006). The new Hadley Centre Climate Model (HadGEM1): evaluation of coupled simulations. Journal of Climate, 19(7), 1327-1353.

Jones, J. W., Hoogenboom, G., Porter, C. H., Boote, K. J., Batchelor, W. D., Hunt, L. A., et al. (2003). The DSSAT cropping system model. European Journal of Agronomy, 18(3-4), 235-265.

Jørgensen, S. E., Kamp-Nielsen, L., \& Jørgensen, L. A. (1986). Examination of the generality of eutrophication models. Ecological Modelling, 32(4), 251-266. 
Kimaro, A. A., Timmer, V. R., Chamshama, S. A. O., Mugasha, A. G., \& Kimaro, D. A. (2008). Differential response to tree fallows in rotational woodlot systems in semi-arid Tanzania: Post-fallow maize yield, nutrient uptake, and soil nutrients. Agriculture, Ecosystems and Environment, 125(1-4), 73-83.

Kimaro, A. A., Timmer, V. R., Chamshama, S. A. O., Ngaga, Y. N., \& Kimaro, D. A. (2009). Competition between maize and pigeonpea in semi-arid Tanzania: Effect on yields and nutrition of crops. Agriculture, Ecosystems and Environment, 134(1-2), 115-125.

KPMG. (2015). Agriculture in Africa Sector Report. Kpmg, 376(9745), 1-18.

Kurukulasuriya, P., Mendelsohn, R., Hassan, R., Benhin, J., Deressa, T., Diop, M., et al. (2006). Will African agriculture survive climate change? World Bank Economic Review, 20(3), 367-388.

Lesch, S. M., Corwin, D. L., \& Robinson, D. A. (2005). Apparent soil electrical conductivity mapping as an agricultural management tool in arid zone soils. Computers and Electronics in Agriculture, 46(1-3), 351-378.

Liben, F. M., Wortmann, C. S., \& Tesfaye, K. (2015). Dry soil planting of maize for variable onset of rainfall in Ethiopia. Agronomy Journal, 107(4), 1618-1625.

Liwenga, E. T. (2008). Adaptive livelihood strategies for coping with water scarcity in the drylands of central Tanzania. Physics and Chemistry of the Earth, 33(8-13), 775-779.

Löhr, K., Hochmuth, C., Graef, F., Wambura, J., \& Sieber, S. (2016). Conflict management programs in trans-disciplinary research projects: the case of a food security project in Tanzania. Food Security. https://doi.org/10.1007/s12571-016-0643-1.

Long, S. P., Ainsworth, E. A., Leakey, A. D., Nosberger, J., \& Ort, D. R. (2006). Food for thought: lower-than-expected crop yield stimulation with rising CO2 concentrations. Science, 312(5782), 1918-1921.

Luhunga, P., Chang'a, L., \& Djolov, G. (2017). Assessment of the impacts of climate change on maize production in the wami ruvu Basin of Tanzania. Journal of Water and Climate Change, 8(1), 142-164.

Lutts, S., Benincasa, P., Wojtyla, L., Kubala, S., Pace, R., Lechowska, K., et al. (2016). Seed Priming: New Comprehensive Approaches for an Old Empirical Technique. In S. Araujo \& A. Balestrazzi (Eds.), New Challenges in Seed Biology - Basic and Translational Research Driving Seed Technology (pp. 1-46). InTech. https://doi.org/10.5772/64420

Mdemu, M. V., Mziray, N., Bjornlund, H., \& Kashaigili, J. J. (2017). Barriers to and opportunities for improving productivity and profitability of the Kiwere and Magozi irrigation schemes in Tanzania. International Journal of Water Resources Development, 33(5), 725-739.

Meinshausen, M., Smith, S. J., Calvin, K., Daniel, J. S., Kainuma, M. L. T., Lamarque, J., et al. (2011). The RCP greenhouse gas concentrations and their extensions from 1765 to 2300. Climatic Change, 109(1), 213-241.

Mmbaga, T. E., \& Lyamchai, C. Y. (2002). Drought management options in maize production in northern Tanzania. In D. K. Friesen \& A. F. E. Palmer (Eds.), Proceedings of the Seventh Eastern and Southern Africa Regional Maize Conference (pp. 281-287). Nairobi: CIMMYT (International Maize and Wheat Improvement Center) and KARI (Kenya Agricultural Research Institute).

Moss, R. H. R. H., Edmonds, J. A. J. A., Hibbard, K. A. K. A., Manning, M. R., Rose, S. K. S. K., van Vuuren, D. P. D. P., et al. (2010). The next generation of scenarios for climate change research and assessment. Nature, 463(7282), 747-756.

Mourice, S. K., Rweyemamu, C. L., Tumbo, S. D., \& Amuri, N. (2014a). Maize cultivar specific parameters for decision support system for agrotechnology transfer (DSSAT) application in Tanzania. American Journal of Plant Sciences, 5(6), 821-833.

Mourice, S. K., Tumbo, S. D., Nyambilila, A., \& Rweyemamu, C. L. (2014b). Modeling potential rain-fed maize productivity and yield gaps in the Wami River sub-basin, Tanzania. Acta Agriculturae Scandinavica, Section B - Soil \& Plant Science, 65(2), 132-140.

Msongaleli, B. M., Rwehumbiza, F., Tumbo, S. D., \& Kihupi, N. (2015). Impacts of climate variability and change on rainfed sorghum and maize: Implications for food security policy in Tanzania. Journal of Agricultural Science, 7(5), 124-142.
Mugalavai, E. M., Kipkorir, E. C., Raes, D., \& Rao, M. S. (2008). Analysis of rainfall onset, cessation and length of growing season for western Kenya. Agricultural and Forest Meteorology, 148(6-7), 1123-1135.

Müller, C., Bondeau, A., Popp, A., Waha, K., \& Fader, M. (2010). Climate Change Impacts on Agricultural Yields. In IATRC Public Trade Policy Research and Analysis Symposium 2010 'Climate Change in World Agriculture Mitigation Adaptation Trade and Food Security (pp. 1-28). http://purl.umn.edu/91393

Mutabazi, K. D., Sieber, S., Maeda, C., \& Tscherning, K. (2015). Assessing the determinants of poverty and vulnerability of smallholder farmers in a changing climate: the case of Morogoro region, Tanzania. Regional Environmental Change, 15(7), 1243-1258.

Muthukuda Arachchi, D. H., Naylor, R. E. L., \& Bingham, I. J. (1999). A thermal time analysis of ageing of maize (Zea mays L.) seed can account for reduced germination in hot moist soil. Field Crops Research, 63(2), 159-167.

Nelson, G. C., Rosegrant, M. W., Koo, J., Robertson, R., Sulser, T., Zhu, T., et al. (2009). Climate change: Impact on agriculture and costs of adaptation. Food Policy.Washington, DC: International Food Policy Research Institute. https://doi.org/10.2499/0896295354

Nelson, G. C., Rosegrant, M. W., Palazzo, A., Gray, I., Ingersoll, C., Robertson, R., et al. (2010). Food security, farming, and climate change to 2050: Scenarios, Results, Policy Options (p 155). Washington, DC: IFPRI. https://doi.org/10.2499/9780896291867.

Pandey, S., Bhandari, H., Ding, S., Prapertchob, P., Sharan, R., Naik, D., et al. (2007). Coping with drought in rice farming in Asia: Insights from a cross-country comparative study. Agricultural Economics, 37, 213-224.

Porter, J. R., \& Semenov, M. A. (2005). Crop responses to climatic variation. Philosophical Transactions of the Royal Society B: Biological Sciences, 360(1463), 2021-2035.

Randall, D. A., Wood, R. A., Bony, S., Colman, R., Fichefet, T., Fyfe, J., et al. (2007). Climate models and their evaluation. In S. Solomon, D. Qin, M. Manning, Z. Chen, M. Marquis, K. B. Averyt, et al. (Eds.), Climate Change 2007: The Physical Science Basis. Contribution of Working Group I to the Fourth Assessment Report of the Intergovernmental Panel on Climate Change (pp. 589-662). Cambridge: Cambridge University Press. https://www.ipcc.ch/pdf/ assessmentreport/ar4/wg1/ar4-wg1-chapter8.pdf.

Reidsma, P., Ewert, F., Lansink, A. O., \& Leemans, R. (2010). Adaptation to climate change and climate variability in European agriculture: The importance of farm level responses. European Journal of Agronomy, 32(1), 91-102.

Rivington, M., \& Koo, J. (2011). Report on the Meta-Analysis of Crop Modelling for Climate Change and Food Security Survey. Foreign Affairs. file:///Users/DURU/Documents/Mendeley Desktop/ Rivington, Koo - Unknown - Report on the Meta-Analysis of Crop Modelling for Climate Change and Food Security Survey.pdf

Rosenzweig, C., Jones, J. W., Hatfield, J. L., Ruane, A. C., Boote, K. J., Thorburn, P., et al. (2013). The Agricultural Model Intercomparison and Improvement Project (AgMIP): Protocols and pilot studies. Agricultural and Forest Meteorology, 170(0), 166-182.

Schlenker, W., \& Lobell, D. B. (2010). Robust negative impacts of climate change on African agriculture. Environmental Research Letters, 5(1), 1-8.

Seo, S. N., Mendelsohn, R., Dinar, A., Hassan, R., \& Kurukulasuriya, P. (2009). A ricardian analysis of the distribution of climate change impacts on agriculture across agro-ecological zones in Africa. Environmental and Resource Economics, 43(3), 313-332.

Shiferaw, B., Tesfaye, K., Kassie, M., Abate, T., Prasanna, B. M., \& Menkir, A. (2014). Managing vulnerability to drought and enhancing livelihood resilience in sub-Saharan Africa: Technological, institutional and policy options. Weather and Climate Extremes, 3, 67-79.

Tao, F. L., \& Zhang, Z. (2010). Adaptation of maize production to climate change in North China Plain: Quantify the relative contributions of adaptation options. European Journal of Agronomy, $33(2), 103-116$. 
Thornton PK, Jones PG, Owiyo T, Kruska RL, Herrero M, Kristjanson P, Notenbaert A, Bekele $\mathrm{N}$ and Omolo A, with contributions from Orindi V, Otiende B, Ochieng A, Bhadwal S, Anantram K, Nair S, Kumar V and Kulkar U (2006). Mapping climate vulnerability and poverty in Africa. Report to the Department for International Development ( $\mathrm{pp}$ 171). Nairobi: ILRI. Source: http://citeseerx.ist.psu.edu/viewdoc/ download?doi=10.1.1.663.1282\&rep=rep1\&type=pdf

Tubiello, F. N., Amthor, J. S., Boote, K. J., Donatelli, M., Easterling, W., Fischer, G., et al. (2007). Crop response to elevated CO2 and world food supply - A comment on "Food for Thought..." by Long et al., Science 312 : 1918-1921, 2006. European Journal of Agronomy, 26(3), 215-223.

Warszawski, L., Frieler, K., Huber, V., Piontek, F., Serdeczny, O., \& Schewe, J. (2014). The Inter-Sectoral Impact Model Intercomparison Project (ISI-MIP): Project framework. Proceedings of the National Academy of Sciences, 111(9), 3228-3232.

Watanabe, S., Hajima, T., Sudo, K., Nagashima, T., Takemura, T., Okajima, H., et al. (2011). MIROC-ESM: model description and basic results of CMIP5-20c3m experiments. Geoscientific Model Development Discussions, 4(2), 1063-1128.

Westengen, O. T., \& Brysting, A. K. (2014). Crop adaptation to climate change in the semi-arid zone in Tanzania: the role of genetic resources and seed systems. Agriculture \& Food Security, 3(1), 3.

Wilkens, P. W., Hoogenboom, G., Porter, C. H., Jones, J. W., \& Uryasev, O. (2004). DSSAT v4 Weather Data Editing Program (Weatherman). In Data Management and Analysis Tools Decision Support System for Agrotechnology Transfer Version 4.0: DSSAT 44 :Data Management and Analysis Tools (Vol. 2, pp. 92151). Honolulu: University of Hawaii.

Willmott, C. J. (1982). Some comments on the evaluation of model performance. Bulletin - American Meteorological Society. http://www.scopus.com/inward/record.url?eid=2-s2.00020386641\&partnerID=tZOtx3y1

Wilson, R. T., \& Lewis, J. (2015). The MAIZE value chain in tanzania. Food and Agriculture Organization of the United Nations (p. 60). Rome, Italy. http://www.saiia.org.za/value-chains-in-southernafrica/1055-008-tanzania-maize/file

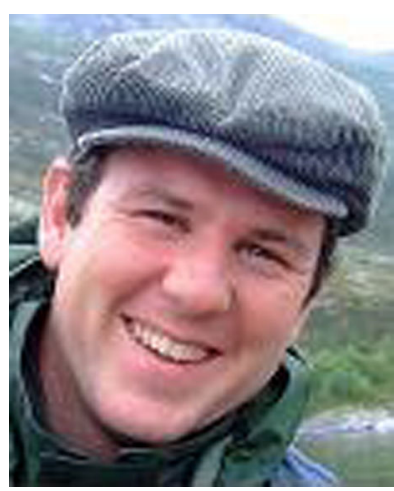

Marcos Alberto Lana holds a degree in Agronomy and a Masters in Agro-ecosystems from the Federal University of Santa Catarina State, Brazil. He holds a Doctoral degree in Crop Production from the ChristiansAlbrecht Universität-Kiel, Germany. Currently Marcos works as scientist and lecturer at the Swedish University of Agricultural Sciences in Uppsala, and as a visiting scientist at the Centre of Agricultural Landscape Research (ZALF), Müncheberg, Germany. His work is focused on the use of crop models to assess the impact of climate change on crops and precision farming, so as to propose suitable adaptation strategies for the rural sector. Marcos is also involved with the development and adoption of agroecology as a tool to support sustainable farming systems. He is active in different regions of Europe, Africa and Latin America. He also teaches at the Humboldt UniversitätBerlin and advises Bachelors, Masters and $\mathrm{PhD}$ students.

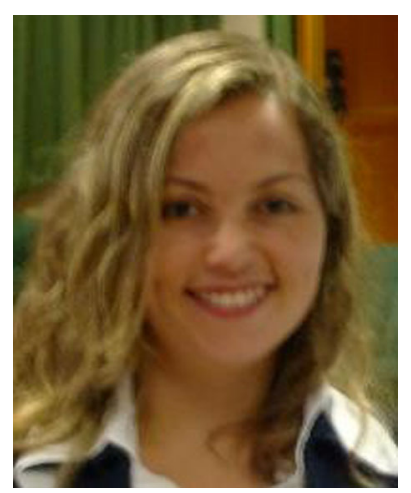

Ana Carolina F. Vasconcelos holds a degree in Agricultural Engineering and a Masters in Development and Environment from the Federal University of Paraíba, Brazil. She holds a PhD in Agronomy (Soil and Plant Nutrition) from the University of São Paulo. Ana has experience in the field of Agricultural Engineering, with emphasis on Soil Fertility and Plant Nutrition, working mainly on salinity, climate change, and adaptation strategies to climate change.

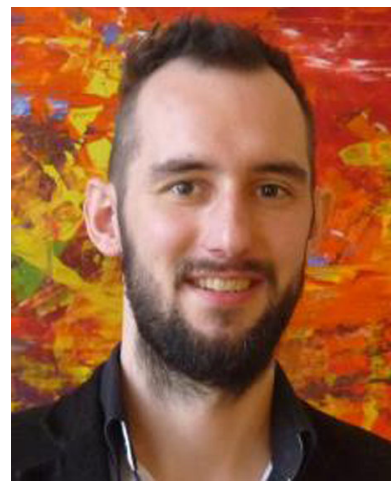

Christoph Gornott has a Masters of Science and is currently a $\mathrm{PhD}$ student at the Potsdam Institute for Climate Impact Research (PIK) in Germany. He is completing his $\mathrm{PhD}$ thesis about regional yield assessments by using statistical and process-based crop models. He is experienced in project management in several ongoing projects. Within the TransSEC (BMBF, BMZ) project, he has four years of experience with crop modelling and food security assessment. At PIK, Christoph has worked on regional crop yield modelling, climate impacts and improvement of agricultural production systems, as well as links between crop field trials and crop modeling. He also has a masters degree in agricultural economics and a bachelors degree in agricultural science (both from the Humboldt University Berlin).

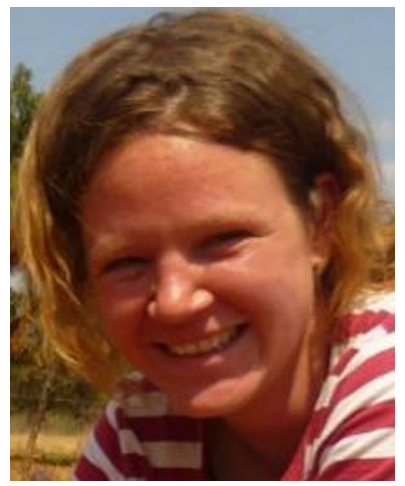

Angela Schaffert holds a Masters Degree in Agricultural Sciences in the Tropics and Subtropics. Currently she is a $\mathrm{PhD}$ student with the University of Hohenheim in Germany. Her ongoing research activities focus on crop water use efficiency in drought-prone areas in Tanzania, with an emphasis on the effect of tied-ridges on soil water conservation. Previously, she did research in southern Ethiopia on the potential of carbon sequestration in savannahs. 


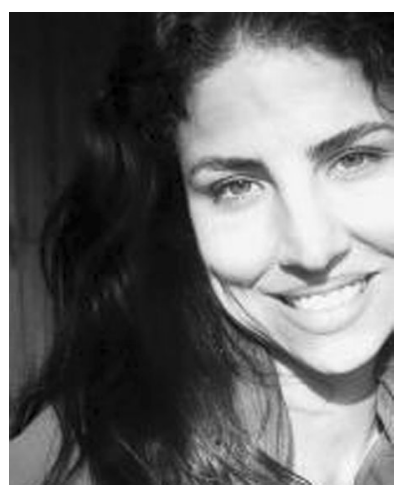

Michelle Bonatti is an Agronomy Engineer from the Federal University of Santa Catarina, Brazil, and holds a Masters degree in Rural Development from Buenos Aires University, Argentina. She is a $\mathrm{PhD}$ student at the Humboldt University of Berlin, working on the development of analytical frameworks and educational response tools to improve food and nutritional security in Tanzania. Michelle is also a Conflict Mediator at the Conflicts Resolution Centre of Santa Catarina State and an Educator for Sustainable Development at Santa Catarina University, Brazil. Over 10 years she has worked in eight research projects, with five NGOs, and has received three prizes for scientific academic performance. Currently Michelle is a scientist with the Centre of Agricultural Landscape Research (ZALF), in Germany.

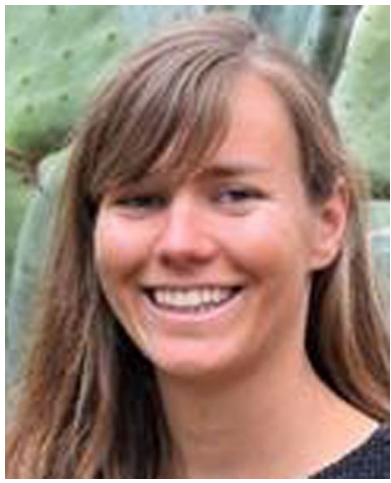

Johanna Volk is a BSc Geographical Sciences student at the Freie Universität Berlin. She is currently working on her thesis in association with the Centre for Agricultural Landscape Research (ZALF) on the impacts of climate change scenarios on rain fed maize production in a sub-region of Tanzania. Johanna is acquiring research skills in crop modelling in order to simulate and analyze future agricultural outputs under different scenarios of climate change. During her studies, she engaged in issues related to food security through a physical and human geography perspective, with an emphasis on soil science and development studies. A fellowship from the German Academic Exchange Service (DAAD) made it possible for her to spend a semester abroad at Stellenbosch University, South Africa and work for a local NGO, the Women on Farms project.

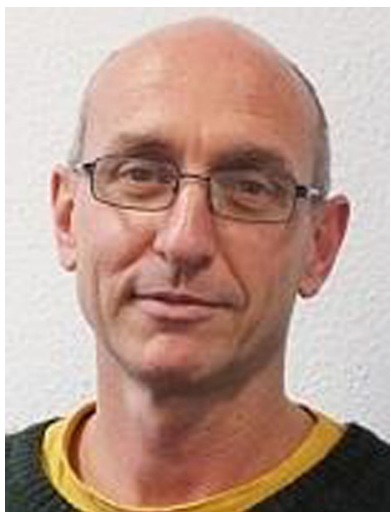

Frieder Graef works at the Centre for Agricultural Landscape $\mathrm{Research}$ ( Z A L F ) in Müncheberg, Germany. He holds a $\mathrm{PhD}$ in tropical agriculture from the University of Hohenheim, Germany, and specialised in soil science, GIS and land evaluation. Frieder is scientific coordinator of the German-Tanzanian research project Trans-SEC. This stakeholder-driven project aims at improving food security for the vulnerable rural poor population in Tanzania, applying upgrading strategies along local and regional food value chains. Previously he worked at the Federal Agency of Nature Conservation
$(\mathrm{BfN})$ in Bonn, Germany, where he was involved in the regulation of genetically modified organisms (GMO). There his special focus was on cultivation systems, and strategies for monitoring their potential effects on biodiversity and ecosystems.

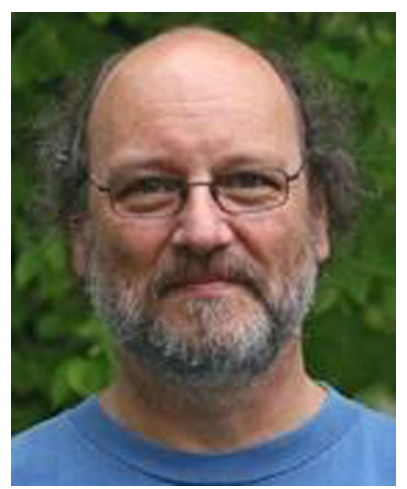

Kurt Christian Kersebaum works as senior scientist at the Institute of Landscape Systems Analysis from the Leibniz Centre for Agricultural Landscape Research - Müncheberg, Germany. He is an agricultural engineer with a $\mathrm{PhD}$ in horticulture and holds a Dr. Habil in geoecology from the University of Potsdam. His main expertise is in agro-ecosystem modelling with a focus on water and matter dynamics, crop growth and climate change. He has authored or co-authored more than 180 scientific works, is the national delegate for Germany in the management committee of COST ES 1106 EU (AGRIWAT Assessment of EUROpean AGRIculture WATer use and trade under climate change), is editorial board member of several scientific journals and associated with different scientific associations. He also received the R. Ahuja Ag. Systems Modeling Award from the American Soil Science Society.

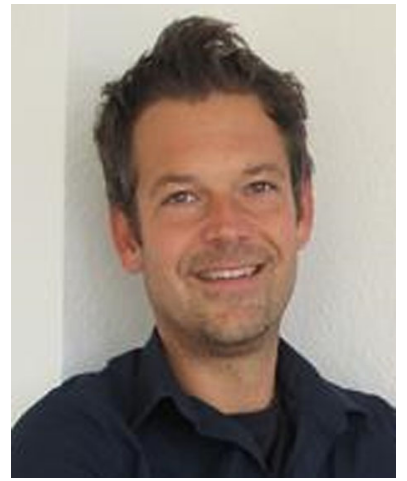

Stefan Sieber is an agricultural economist working as a senior scientist and head of the department of Economics of Sustainable Land Use at the Centre of Agricultural Landscape Research (ZALF). He holds a $\mathrm{PhD}$ in agricultural sciences from the University of Bonn. He has extensive experience in agricultural sector modelling, particularly in terms of impact assessment of environmental and sustainability policies and in applied monitoring and evaluation methods of international development projects worldwide (Europe, Latin America and Africa). Stefan has managed more than 25 research projects and has authored or co-authored more than 35 peer-reviewed publications, 12 peer-reviewed contributions for books and research series, as well as 80 conference papers. He is currently completing his second $\mathrm{PhD}$ (Habilitation) and is a lecturer on the master's program "Environmental Sociology and Environmental Policy" at the Humboldt University of Berlin. 